\title{
A SANTIDADE DO CONTRATO E DAS LEIS: CONSIDERAÇÕES SOBRE A RELIGIÃO CIVIL DE ROUSSEAU
}

\author{
Thomaz Kawauche* \\ kawauche@gmail.com
}

\begin{abstract}
RESUMO No capitulo sobre a religião civil no Contrato social, Rousseau utiliza expressões como "santidade do contrato social e das leis", "profissão de fé puramente civil", e mesmo "religião civil" para fazer alusão à relação necessária, porém conflituosa, entre religião e política. Neste artigo, trata-se de discutir esse expediente retórico (que é similar à figura de linguagem denominada oxímoro) de um ponto de vista mais geral, com base na exposição do procedimento discursivo do legislador do Contrato e de suas semelhanças com o procedimento discursivo do próprio Rousseau para conciliar exigências contraditórias da religião e da política no problema da instituição das leis no Estado.
\end{abstract}

Palavras-chave Religião, política, retórica, figura de linguagem.

ABSTRACT In the chapter about civil religion in the Social Contract, Rousseau uses expressions such as "sanctity of social contract and laws", "purely civil profession of faith", and even "civil religion" for alluding to the necessary, although conflicting, relation between Religion and Politics. This article aims at discussing this rhetoric device (that is similar to the figure of speech named oxymoron) from a more general point of view, based on the exposition of Contract's legislator speech procedure and of the similarities with Rousseau's speech procedure to conciliate the contradictory exigencies of Religion and Politics in the problem of laws'institution in State. 
Keywords Religion, politics, rhetoric, figure of speech.

No capítulo 8 do quarto livro do Contrato social, Rousseau enumera os dogmas de sua "profissão de fé puramente civil":

Os dogmas da religião civil devem ser simples, em pequeno número, enunciados com precisão, sem explicações nem comentários. A existência da divindade poderosa, inteligente, benfazeja, previdente e providente, a vida futura, a felicidade dos justos, o castigo dos maus, a santidade do contrato social e das leis; são estes os dogmas positivos. Quanto aos dogmas negativos, limito-os a um só: a intolerância, que diz respeito aos cultos que excluímos. (O.C. III, p. 468-469)

Dos cinco dogmas positivos, observa-se que os quatro primeiros são essencialmente teológicos: (1) a existência de Deus e a afirmação de seus atributos, (2) a vida futura, (3) a felicidade dos justos, e (4) o castigo dos maus. Contudo, o quinto dogma apresenta, em sua expressão, uma mistura inusitada entre religião e política: "a santidade do contrato social e das leis". Percebe-se então uma espécie de descontinuidade, ou ainda, uma anomalia na sequência dos dogmas puramente teológicos. E mesmo quando se considera o último dogma, que Rousseau classifica como "negativo" por tratar-se de uma proibição à intolerância, ainda assim o dogma da santidade do contrato e das leis continua destoando no conjunto. Pois, muito embora na proscrição à intolerância também esteja implicada uma tensão entre o civil e o teológico - que Rousseau discute no parágrafo seguinte, afirmando que a intolerância teológica não se distingue da intolerância civil -, é somente no quinto dogma que os termos políticos são colocados explicitamente, isto é, no ato mesmo da declaração do dogma. Trata-se de uma curiosa ligação entre palavras que, a princípio, seriam incompatíveis devido à clássica oposição entre a esfera do divino e a do humano: afinal, referir-se à "santidade" de instituições tão profanas como o contrato social e as leis não deixa de causar um certo estranhamento, visto que normalmente tal atributo é empregado pelos teólogos quando falam da natureza "sagrada" de Deus ou de suas obras, e que o próprio Rousseau utiliza para fazer menção ao Evangelho. ${ }^{2}$

1 Para as citações dos textos de Rousseau, utilizamos a edição das Oeuvres Complètes de Jean-Jacques Rousseau, publicada sob direção de B. Gagnebin e M. Raymond (ROUSSEAU, 1959-1995), que indicamos por "O.C." seguido do número do volume e da paginação do texto citado. A tradução consultada para os textos do Contrato foi a de Antonio de Pádua Danesi (ROUSSEAU, 2003), a qual foi modificada sempre que isso nos pareceu necessário.

2 No Emílio, apenas para citarmos dois exemplos, Rousseau se refere ao "sagrado caráter da divindade" (O.C. IV, p. 613) e à "santidade do Evangelho" (O.C. IV, p. 625). 
A peculiaridade do quinto dogma da religião civil não é mais novidade hoje: todavia, ela foi apontada apenas recentemente, por Ghislain Waterlot, num estudo sobre religião e política em Rousseau. ${ }^{3}$ Para esse comentador, o dogma em questão se destaca dos demais pelo fato de ser o único que evoca explicitamente a política e não encontra correspondente na Profissão de fé do vigário saboiano, opúsculo do livro IV do Emílio onde Rousseau discorre sobre a religião natural. No presente artigo, trata-se de fazer uma pequena contribuição ao estudo de Waterlot mediante o exame da seguinte hipótese: que o dogma da santidade do contrato e das leis se destaca dos demais não apenas por ser um dogma político e sem equivalente na Profissão de fé, mas também por estar associado a um expediente retórico de Rousseau similar à figura de linguagem denominada oxímoro, que se verifica não apenas em outros momentos do capítulo sobre a religião civil, mas também, num nível mais geral da obra, em uma passagem fundamental do Contrato encontrada no capítulo sobre o legislador. Temos em vista aqui, portanto, as implicações do uso retórico de um vocabulário teológico no registro do discurso político acerca da instituição das leis no Estado ideal de Rousseau.

Analisar expressões como "santidade do contrato", "profissão de fé puramente civil" e "religião civil", que trazem em seu bojo a tensão resultante das contradições entre religião e política, parece-nos um primeiro passo necessário para a compreensão não apenas dos efeitos sociais implicados nessa mesma relação segundo Rousseau, mas também das divergências e das polêmicas entre os comentadores do Contrato social (daí considerarmos significativo que Lelia Pezzillo tenha se referido ao "raciocínio confuso"

3 WATERLOT, 2004, p. 88. Em geral, os comentadores - dentre os quais se destaca Pierre-Maurice Masson (1916, t. II, p. 185, 199 etc.) - se preocupam em analisar a função política dos dogmas da religião civil de Rousseau. Roger Masters chegou a notar que não havia um correspondente do quinto dogma entre os dogmas da Profissão de fé, mas ele se limitou a explicar essa diferença em termos de uma substituição: para esse comentador, o dogma da santidade do contrato e das leis teria apenas substituído os ensinamentos sobre benevolência e piedade do Emílio (cf. MASTERS, 1968, p. 88).

4 "O resultado é um raciocínio confuso que aspiraria à união de exigências perfeitamente contraditórias. Rousseau não pretende renunciar ao princípio do Estado 'laico' e da liberdade de consciência, mas não chega a se libertar da ideia, muito banal e corrente na época, de que a religião é uma garantia indispensável da moralidade, e que uma sociedade deve banir aqueles que negam a existência de Deus pelo fato de não oferecerem nenhuma segurança de lealdade [...]." (PEZZILLO, 2000, p. 112). Pode-se dizer que tal confusão se reflete nos comentários dos estudiosos, que oscilam entre os aspectos religiosos e políticos do problema: alguns identificam um movimento de "laicização do Estado" (GOUHIER, 1970, p. 255) por meio do qual assistimos a uma "politização da religião" (PISSARRA, 1988, p. 135-136), enquanto outros referem-se a uma "sacralização da ordem político-social" (SALINAS FORTES, 1997, p. 137), ou ainda, a uma "divinização do Estado" (COTTA, 1965, p. 190). A confusão também se verifica no modo como os comentadores interpretam os efeitos sociais da religião civil na realidade histórica: há quem afirme que a religião civil de Rousseau traz em seus dogmas os "germes da intolerância" (DERATHÉ, 1959-1962, p. 180), seguindo um raciocínio similar àquele que identifica a religião civil do Contrato a uma "religião secular" defendida por alguns pensadores do século XVIII e que teria servido como uma das 
de Rousseau sobre o assunto). Lembremos que Louis Althusser ${ }^{5}$ indica, no Contrato, problemas de ordem interna ao texto, intrínsecos à lógica mesma do discurso - as "décalages" associadas ao objeto "contrato social" -, mostrando que a diversidade de interpretações sobre o pacto poderia ser compreendida a partir da análise desses problemas internos, o que nos remete a leituras que enfocam os aspectos retóricos da obra de Rousseau. Tal abordagem, que consideramos adequada diante das polêmicas em torno da religião civil do Contrato $^{6}$, pode ser justificada com base nos comentários de Peter Jimack ${ }^{7}$, Simone Goyard-Fabre ${ }^{8}$ e Francine Markovits 9 .

bases ideológicas da "democracia totalitária" (TALMON, 1952, p. 9, 21-24, 43); mas outros defendem que, levando-se em conta o contexto em que é apresentada, a religião civil pode ser considerada uma "religião da tolerância" (SALINAS FORTES, p. 153) ou uma "instituição de tolerância" (BERNARDI, 2009, p. 167). A religião civil também é estudada na perspectiva das ciências sociais, sendo muito conhecido o artigo "Civil Religion in America", de Robert Bellah (1991[1967]). Tomando como base o conceito de religião civil de Rousseau, Bellah analisa alguns discursos de presidentes dos Estados Unidos (Washington, Lincoln, Johnson e Kennedy) a fim de demonstrar que as crenças, os símbolos e os ritos centrados na ideia de Deus não apenas desempenharam um papel constitutivo no pensamento dos homens de Estado americanos, mas também foram compartilhados pela maioria dos cidadãos daquele país. Segundo Bellah, a "American life" teria sido instituída com base nessa "religião civil". O artigo gerou muita polêmica e uma crítica recente com balanço da imensa bibliografia sobre o tema encontra-se no livro de Marcela Cristi (2001). Para essa autora, Bellah comete um anacronismo, pois confunde a religião civil de Rousseau com a concepção durkheimiana de religião. Um dos méritos do livro de Cristi é o cuidado que a autora demonstra ao estabelecer a distinção conceitual entre "religião civil" (dos estudos contemporâneos sobre o assunto) e "religião política" (que seria a religião que Roussau apresenta no Contrato social).

5 Althusser (1967).

6 Pois, de acordo com Jean Ferrari, a religião civil não possui correspondente necessário na realidade histórica, de modo que, assim como o pacto civil, pode ser considerada um objeto de discurso que se mostra infiel em relação às exigências práticas ora da política, ora da religião. Tal constatação nos remete a problemas similares àqueles tratados por Althusser (a religião civil poderia apontar para outra décalage na cadeia de décalages originadas no pacto), o que justificaria uma análise da religião civil de Rousseau do ponto de vista da retórica: "A religião civil é uma solução proposta por Rousseau que permite a conciliação entre o religioso e o político, mas não sem algum afastamento ou infidelidade em relação a um e a outro. [...] assim como o próprio pacto social, a religião civil pode ser considerada uma ideia da razão destinada a conjurar as desordens da cidade. Ela é uma espécie de auxiliar ideal para o convencionalismo do Contrato social." (FERRARI, 1995, p. 98).

7 Jimack (1965) afirma, numa leitura bastante radical, que a Profissão de fé do vigário saboiano deve ser analisada não em termos de seu conteúdo, mas única e exclusivamente de sua forma. O comentador aponta para diversos aspectos retóricos na composição do texto, como a escolha dos termos, a repetição de palavras e as construções para enfatizar uma determinada ideia, os quais teriam em vista apenas a "efetividade estilística" (Ibid., p. 26), de modo que as referências à religião no Emílio diriam respeito "não à fé do Rousseau cristão, mas à eloquência do Rousseau artista" (Ibid., p. 27). Parece-nos que as mesmas observações que Jimack faz em relação ao Emílio são pertinentes no caso do capítulo sobre a religião civil do Contrato social, que, como sabemos, foi resultado de muitas correções por parte de Rousseau.

8 Goyard-Fabre (2001) investiga a gênese da expressão "religião civil" para compreender, no Contrato, a divergência de interpretações sobre a relação entre política e religião. A justificativa textual é evidente: o próprio Rousseau recomenda "um pouco mais de precisão nas ideias muito vagas sobre religião" (O.C. III, p. 464) como requisito para a correta colocação do problema. Para a comentadora, são as dicotomias entre "religião do homem" e "religião do cidadão" e entre "religião natural" e "religião civil", que fornecem a Rousseau a sub-estrutura categorial para a meditação política sobre a religião civil no Contrato, donde se justificaria o primado dos aspectos semânticos no estudo em questão: "É sobre esta base que, com efeito, serão lançadas, no verso das folhas consagradas ao 'Legislador', as notas de trabalho que formam o rascunho do último capítulo do Contrato social. A problemática tomou desde já uma forma radical e o vocabulário se revestiu de intrepidez. Rousseau, sem temer a aliança das palavras que provocará 
Que o capítulo sobre a religião civil no Contrato é repleto de oposições entre termos inconciliáveis, isso pode ser facilmente verificado até mesmo mediante uma leitura superficial do texto. Rousseau desenvolve seus argumentos contrapondo os seguintes pares: sociedade geral e sociedade particular, cristianismo de hoje e cristianismo do Evangelho, vida presente e vida futura, liberdade e escravidão. Grosso modo, por meio da análise comparativa o autor visa extrair algumas conclusões a partir dos contrastes entre os termos contrários. Até aí, nada de mais, uma vez que esse procedimento é bastante conhecido entre os estudiosos da obra do Cidadão de Genebra, podendo até ser considerado uma espécie de método rousseauniano para elaboração do conhecimento. No entanto, em certos momentos, Rousseau não se limita ao estudo das diferenças, mas também se esforça por evidenciar a necessidade de algum tipo de conciliação entre os termos contrapostos. É o que se observa, por exemplo, na oposição entre poder eclesiástico e poder civil.

Retomemos o texto do capítulo "Da religião civil" para melhor situarmos nossa análise. Após o aparecimento de Jesus e a implantação de seu reino espiritual na terra, os homens passam a dividir suas preocupações entre a pátria terrena e a pátria celeste. Tal episódio marca um divisor de águas na história narrada por nosso autor: o advento do cristianismo promove a funesta separação entre o sistema teológico e o sistema político, o que resulta na perda de unidade do Estado e no surgimento de um conflito envolvendo poder civil e poder eclesiástico. Em meio a esse novo quadro político-religioso, a manutenção da ordem social torna-se um problema bastante complicado de ser resolvido. Afirma Rousseau: "No entanto, como sempre houve um príncipe e leis civis, resultou desse duplo poder um conflito perpétuo de

escândalo, se empenha em clarificar, sob a expressão, desta vez explícita, de "religião civil", o que, na Cidade, pode se reportar à 'religião' do homem e o que diz respeito à 'religião' do cidadão. Importa a seus olhos, para além das evidências trazidas pela história, de afastar, se se quer ir ao fundo do problema, as vertigens semânticas da palavra 'religião'." (GOYARD-FABRE, 2001, p. 125).

9 Markovits (2003), ao examinar a questão da religião natural do ponto de vista da análise do discurso, mostra que Rousseau se interessaria menos pelos conteúdos dos pensamentos positivos do que por suas condições de enunciação, que diriam respeito às crenças de um sujeito determinado: "As crenças enquanto saberes fracos, falsos ou, melhor, ilusórios têm efeitos. A realidade delas não se discute. E seu atrativo não diz respeito à sua verdade, mas a sua utilidade." (Ibid., p. 216). Com isso, a comentadora defende a necessidade de se deslocar a leitura dos escritos de Rousseau do âmbito da verdade para o da utilidade, a fim de que os textos sejam interrogados não em termos da sinceridade do autor ou da correspondência entre discurso e realidade (donde viria a grande massa de interpretações divergentes sobre o tema), mas das formas do discurso e das posições do sujeito de enunciação. 
jurisdição que tornou toda boa politia ${ }^{10}$ impossível nos Estados cristãos; e jamais se conseguiu saber se era ao senhor ou ao padre que se estava obrigado a obedecer." (O.C. III, p. 462).

Notemos que a crítica de Jean-Jacques se volta contra o "duplo poder" - do senhor e do padre -, visto que ele resulta em um "conflito perpétuo" entre os domínios da religião e da política. Nesses termos, o cristianismo seria nocivo ao espírito social exatamente pelo fato de estabelecer, no interior da sociedade, a oposição entre poder civil e poder eclesiástico, causando assim divisões internas que culminariam na morte do corpo político. A solução que Rousseau parece vislumbrar para a preservação da sociedade encontra-se na restauração da unidade do Estado mediante a reunião dos dois poderes. Daí o sentido do elogio feito ao governo de Maomé, cujo mérito estaria precisamente no fato de não fazer distinção entre o sistema político e a religião islâmica:

Maomé teve em vista coisas muito salutares, ligou bem seu sistema político e, enquanto a forma de seu governo subsistiu sob a direção dos califas seus sucessores, esse governo foi exatamente uno e, por isso, bom. Mas os árabes, tornando-se florescentes, letrados, polidos, fracos e covardes, foram subjugados por bárbaros e, então, recomeçou a divisão entre os dois poderes. (O.C. III, p. 462-463)

E é justamente com o intuito de solucionar essa dicotomia nociva de poderes que, alguns parágrafos mais adiante, Rousseau elogia Hobbes: "De todos os autores cristãos, o filósofo Hobbes é o único que viu muito bem o mal e o remédio, que ousou propor reunir as duas cabeças da águia e reconduzir tudo à unidade política, sem a qual jamais Estado e Governo serão bem constituídos." (O.C. III, p. 463).

Ora, como sabemos, Rousseau não admitia a teoria política de Hobbes. É preciso, pois, notar que esse elogio ao filósofo inglês refere-se tão-somente à proposta de "reunir as duas cabeças da águia", isto é, ao restabelecimento da ligação entre poder civil e poder eclesiástico. E mesmo assim, o "remédio" prescrito por Hobbes não estaria isento, na opinião de Rousseau, de sérios efeitos colaterais, visto que a religião em questão era o cristianismo, o que tornaria difícil, ou até mesmo impossível, a aliança entre Igreja ao Estado. É por isso que Rousseau afirma: "Mas ele [Hobbes] deveria ver que o espírito dominador do cristianismo era incompatível com seu sistema, e que o interesse do padre seria sempre mais forte que o do Estado." (O.C. III, p. 463).

10 Rousseau utiliza politie, uma forma que caiu em desuso segundo Littré. A forma mais usual em língua francesa, police, diz respeito ao governo ou, mais especificamente, à regulamentação social que assegura a vida cômoda e tranquila almejada em todas as sociedades, cf. verbete "Police", no volume XII da Encyclopédie, publicado em 1765. 
O que se evidencia na leitura das passagens citadas é, portanto, uma preocupação no sentido de ligar duas instâncias - a da religião e a da política - que, muito embora devam estar necessariamente unidas para evitar o desmembramento do corpo político, encontram-se todavia radicalmente separadas nas modernas sociedades européias, não podendo coexistir a não ser de maneira conflituosa. É exatamente esse princípio de conciliar exigências contraditórias da religião e da política para a manutenção do corpo político que encontramos na ideia de religião civil no Contrato. Contudo, para melhor compreendermos esse "raciocínio confuso"", devemos acompanhar os desdobramentos que Rousseau realiza para chegar à fórmula de sua "profissão de fé puramente civil", a qual, como ele mesmo afirma nas Cartas escritas da montanha, corresponde à conclusão de suas pesquisas "sobre o modo pelo qual a religião pode e deve entrar como parte constitutiva na composição do corpo político" (O.C. III, p. 809).

Basicamente, nosso autor define a religião civil a partir da comparação entre dois tipos de religião: a "religião do homem" e a "religião do cidadão". A religião do homem, que diz respeito à sociedade geral, tem a vantagem de reunir todos os homens, levando-os a se respeitarem uns aos outros como irmãos. Rousseau se refere a ela como "religião santa, sublime, verdadeira", por meio da qual "os homens, filhos do mesmo Deus, reconhecem-se todos como irmãos, e a sociedade que os une não se dissolve nem com a morte". No entanto, a religião do homem tem o defeito de fazer com que os indivíduos se preocupem menos com a pátria terrena do que com a pátria celestial, de tal maneira que os seus seguidores dificilmente encontram-se dispostos a morrer por seu país. Daí o porquê de Rousseau afirmar que essa religião não tem "nenhuma relação particular com o corpo político", e que "longe de ligar os corações dos cidadãos ao Estado, desprende-os, como de todas as coisas da terra" (O.C. III, p. 465).

Já a religião do cidadão, que diz respeito à sociedade particular, tem a vantagem de fazer com que seus seguidores sejam bons cidadãos nesta vida. Como explica Rousseau, essa religião "é boa por unir o culto divino ao amor pelas leis e porque, fazendo da pátria objeto da adoração dos cidadãos, ensinalhes que servir o Estado é servir o deus tutelar". Ou seja, a religião do cidadão é útil para promover a coesão social. O defeito está no fato de tratar-se de uma religião nacional exclusivista, o que faz com que seus seguidores sejam intolerantes em relação aos membros de outros corpos políticos: a religião do 
cidadão, nas palavras de nosso autor, é má “quando, tornando-se exclusiva e tirânica, torna um povo sanguinário e intolerante, de forma que ele só respira morte e massacre, e crê praticar uma ação santa ao matar qualquer um que não admita seus deuses" (O.C. III, p. 464-465).

Ora, é bem conhecida a crítica de Rousseau à intolerância, tanto civil quanto teológica, de modo que o nacionalismo resultante do culto à pátria por parte dos adeptos da religião do cidadão não poderia ser bem visto por alguém que se preocupa em defender a tolerância com tanta veemência. Lembremos a observação de nosso autor: "Atualmente, quando não existe mais e não pode mais existir qualquer religião nacional exclusiva, devem-se tolerar todas aquelas que toleram as demais [...]" (O.C. III, p. 469). Além disso, não podemos nos esquecer que, na conclusão do Contrato, Rousseau esboça um pequeno resumo de seu projeto das Instituições políticas, texto no qual ele ampliaria o escopo de sua reflexão tratando do direito entre os povos, isto é, daquilo que hoje chamamos de relações internacionais. Evidentemente, algo como a religião do cidadão, com todo o seu apelo xenófobo, seria completamente descabido em um sistema político de viés cosmopolita como o das Instituições.

Por outro lado, o espírito tolerante dos seguidores da religião do homem não seria de grande valia na sociedade do pacto, uma vez que o corpo político precisa de um mínimo de amor à pátria para subsistir. Na concepção de Rousseau (e dos contratualistas em geral), a sociedade simplesmente não pode se manter com laços frouxos ligando seus membros, de tal modo que a religião do homem, que desprende os corações dos cidadãos das coisas da vida presente, se torna completamente inútil para o estabelecimento da unidade do Estado. Esse é o ponto central da crítica que Rousseau faz ao cristianismo: "O cristianismo é uma religião inteiramente espiritual, preocupada unicamente com as coisas do céu, não pertencendo a pátria do cristão a este mundo. É verdade que ele cumpre o seu dever, mas o faz com uma indiferença profunda quanto ao bom ou mau sucesso de seus trabalhos." (O.C. III, p. 466). Daí o sentido do juízo contra o cristianismo que muito desagradou os clérigos, tanto católicos quanto protestantes: "Não conheço nada mais contrário ao espírito social." (O.C. III, p. 465). ${ }^{12}$

Em suma, o que Rousseau nos apresenta é um quadro de impossibilidades para o problema político da religião. Não podendo optar pela religião do homem nem pela religião do cidadão - e muito menos pelo cristianismo 
romano, que Rousseau descarta de imediato por apresentar somente desvantagens -, torna-se evidente a necessidade de uma religião alternativa, de outra natureza, denominada por nosso autor de religião civil. Devemos notar que a religião civil não se confunde com a religião do cidadão: como afirma Ghislain Waterlot, trata-se de uma "invenção, algo totalmente novo", como se fosse um composto resultante da "mistura química" entre dois elementos: a religião do homem e a religião do cidadão. ${ }^{13}$ Nesses termos, a metáfora da química seria, do ponto de vista da retórica, um recurso de Rousseau para expressar em seu discurso a necessidade da união conflituosa entre religião e política, ou ainda, a conciliação necessária entre as exigências da sociedade geral (associada à religião do homem) e da sociedade particular (associada à religião do cidadão): para o pensador genebrino, a arte política seria uma arte da mistura de elementos distintos e até mesmo excludentes entre si, sendo religião e política dois dos componentes do produto final, que é o Estado. ${ }^{14}$

Em termos mais propriamente políticos, a religião civil encontra seu fundamento na necessidade de uma (in)tolerância moderada - isto é, nem tão tolerante quanto a religião do homem, nem tão intolerante quanto a religião do cidadão -, cuja força coercitiva bem regulada resultasse em sentimentos de amor à pátria na justa medida, seja impedindo manifestações de exclusivismo nacionalista por parte dos cidadãos, seja evitando que a pátria terrena perca suas particularidades e acabe se tornando universal - e, por conseguinte, indeterminada - como a pátria celeste. Por esse motivo, a proposta da religião civil demonstra um esforço de Rousseau no sentido de combinar os pontos positivos da religião do homem e da religião do cidadão (isto é, tolerância e coesão social) e, ao mesmo tempo, evitar os defeitos de cada uma delas (isto é, desapego à pátria terrena e intolerância). Esse esforço de combinação (ou de mistura, para utilizar a metáfora da química sugerida por Waterlot e retomada por Bernardi) fica mais claro em um trecho da primeira versão do capítulo sobre a religião civil, não obstante o fato de Rousseau tê-lo suprimido na versão de 1762:

13 WATERLOT, 2004, p. 89.

14 Notemos, seguindo o comentário de Bruno Bernardi, o vocabulário da química empregado por Rousseau ("parte constitutiva", "composição") para se referir à instituição do corpo político: é o paradigma da química que, segundo Bernardi, permite a Rousseau apresentar a arte política como arte da mistura, o que evidencia o interesse do Cidadão de Genebra, não apenas pelo produto final do processo por meio do qual o Estado é instituído, mas também pelo próprio processo de composição de seu discurso (cf. BERNARDI, 2006, p. 163-172). Nossa análise aqui visa exatamente mostrar como o procedimento discursivo de Rousseau apreende e expressa, por meio de um expediente retórico, a arte política como esse processo que mistura religião e política. 
Assim reunir-se-ão as vantagens da religião do homem e da [religião] do cidadão. O Estado terá seu culto e não será inimigo de nenhum outro [culto]. As leis divina e humana reunir-se-ão sempre sobre o mesmo objeto, os mais piedosos teístas serão também os mais zelosos cidadãos e a defesa das santas leis será a glória do Deus dos homens. (O.C. III, p. 342)

Poderíamos dizer que a religião civil se apresenta, nesse sentido, como um meio-termo, ou uma via média, entre as exigências conflitantes e contraditórias de uma relação difícil, porém necessária, entre poder civil e poder eclesiástico no interior do corpo político. Trata-se, antes de tudo, de uma abordagem prática para o problema que Rousseau se propõe discutir: como o cristianismo não pode assumir formas nacionais sem consequências sociais nocivas, e como as religiões nacionais são intolerantes quanto às diferenças entre corpos políticos em meio ao gênero humano, a religião civil, enquanto profissão de fé do cidadão, se apresentaria como uma forma alternativa de religiosidade, correspondendo a um ponto de equilíbrio em meio aos prós e contras implicados nas relações entre Igreja e Estado. Não que Rousseau estivesse propondo uma solução de fato, pois, como veremos, essa religião (na verdade, um credo mínimo) que serve para qualquer sociedade particular sem contudo poder ser considerada universal, na verdade não resolve nenhuma contradição: em vez disso - e esse é o ponto que importa notar -, nosso autor estaria apenas tentando reduzir a tensão resultante da combinação entre religião e política ao buscar estratégias que pudessem amenizar a intolerância entre as nações, porém, sem que isso implicasse em qualquer tipo de enfraquecimento da coesão social.

Mas o que consideramos mais notável no capítulo "Da religião civil" é o modo como Rousseau constrói seu texto: fazendo a oposição entre termos inconciliáveis, ele não visa exatamente uma síntese, até mesmo porque as contradições permanecem em aberto no texto. A religião civil não substitui as religiões históricas, que devem ser respeitadas, e o processo não pode ser considerado dialético no sentido hegeliano. ${ }^{15}$ Em vez disso, a estratégia do autor consiste em manter a oposição, porém, utilizando-a para estabelecer suas conclusões do tipo via média, sem necessariamente resolver qualquer contradição. Como afirma Waterlot, a religião civil "mantém um grau de

15 Como explica Vargas, Rousseau resolve as contradições pela escolha de um dos termos ou mostrando que eles são complementares entre si, sem nunca sugerir qualquer tipo de síntese, isto é, a transformação dos termos em uma coisa nova, de modo que não haveria em Rousseau uma dialética no sentido hegeliano (cf. VARGAS, 1995, p. 28). É o que verificamos na oposição entre religião do homem e religião do cidadão (para a qual a religião civil representaria a complementaridade dos termos inconciliáveis), e, num nível mais geral, entre a Profissão de fé do vigário saboiano e o capítulo sobre a religião civil do Contrato, que nos remete ao dilema da escolha entre o homem ou o cidadão. 
tensão entre dois pólos". ${ }^{16} \mathrm{Na}$ terminologia da retórica, esse expediente seria algo similar à figura de linguagem denominada oxímoro. Similar porque, a rigor, o oxímoro se estabelece mediante termos contrários do ponto de vista semântico (alto/baixo, grande/pequeno, claro/escuro etc.), e, no caso do texto rousseauniano, religião e política são termos que se contrapõem do ponto de vista ideológico.

De qualquer maneira, trata-se de um recurso estilístico por meio do qual Rousseau aproxima elementos inconciliáveis, mostrando que a relação é ao mesmo tempo necessária e conflituosa. Rousseau denomina sua proposta como "profissão de fé puramente civil", que, assim como o título do capítulo - "religião civil" -, encerra, em uma única expressão, termos que marcam um conflito radical envolvendo religião e política, os quais, justamente devido ao conflito, permitem a Rousseau manter a tensão no produto final da mistura e, assim, escapar de um retorno à teologia-política, que colocaria o fundamento do Estado em uma instância transcendente (a ênfase não deixa de ser notável: puramente civil...). Não é difícil perceber que se trata do mesmo expediente retórico que encontramos na expressão do quinto dogma: "a santidade do contrato social e das leis".

Vamos agora deslocar a análise para um nível mais geral de discussão passando para o capítulo sobre o legislador no livro II do Contrato, que também diz respeito ao nosso problema. ${ }^{17}$ Notemos, primeiramente, que o mesmo expediente retórico por meio do qual Rousseau relaciona religião e política no capítulo sobre a religião civil aparece em um momento fundamental na démarche do Contrato - momento este que consideramos um dos mais delicados da teoria política de Rousseau -, a saber, o da passagem da ideia de vontade geral para a de lei. O texto que nos permite tecer algumas observações é o seguinte:

Eis o que, em todos os tempos, forçou os pais das nações a recorrerem à intervenção do céu e a honrar nos deuses sua própria sabedoria, a fim de que os povos, submetidos às leis do Estado como às da natureza e reconhecendo os mesmos poderes na

16 WATERLOT, 2004, p. 94.

17 A ligação entre o capítulo "Da religião civil" (livro IV, cap. 8) e o capítulo "Do legislador" (livro II, cap. 7) no Contrato foi sugerida tanto do ponto de vista da composição da obra (Derathé explica que uma primeira versão do capítulo sobre a religião civil aparece no verso do capítulo sobre o legislador no Manuscrito de Genebra, cf. O.C. III, Notes et variantes, p. 1498) quanto do ponto de vista da estrutura da obra (por meio da ideia da relação entre a lei e os costumes, cf. GOLDSCHMIDT, 1984, p. 140). 
formação do homem e na da Cidade, obedecessem com liberdade e se curvassem docilmente ao jugo da felicidade pública. (O.C. III, p. 383)

O que está em questão nesse trecho é o princípio de se associar a obediência às leis à obediência aos deuses, que Maquiavel já havia enunciado nos Discursos sobre a primeira década de Tito Livio (livro I, cap. 11), citado por Rousseau em uma nota do Contrato. ${ }^{18} \mathrm{~A}$ versão desse princípio apresentada pelo Cidadão de Genebra tem como novidade o fato de associar as ideias de lei e liberdade, atrelando-as a uma instância superior relativamente ao reino das paixões: o plano da vontade geral. Em uma palavra, trata-se de resolver o problema de colocar a lei acima dos homens, que tivemos oportunidade de discutir em outro lugar. ${ }^{19}$ Aqui, importa-nos observar apenas que, para Rousseau, o homem em sociedade só é livre na medida em que se conforma à vontade geral como se estivesse se conformando a uma vontade divina. E é com base nesse princípio que o legislador realiza seu procedimento discursivo, por meio do qual mistura elementos da religião e da política a fim de persuadir os cidadãos de que as leis civis expressam a vontade divina, estando esta associada, de alguma maneira, à vontade geral. Assim, a liberdade no estado civil se define como submissão à lei por conta da expressão do caráter sagrado da vontade geral, muito mais do que pelo conhecimento dessa vontade em si mesma, coisa que, para Rousseau, o povo seria de todo modo incapaz de fazer.

Sem entrarmos nos detalhes do capítulo em questão, observamos apenas que, do ponto de vista metafórico, o legislador é uma espécie de intermediário entre deus e os homens, e que tem como missão transformar a natureza humana, efetivando assim, como que por um milagre, a passagem do estado de natureza para o estado civil: "Aquele que ousa empreender a instituição de um povo deve se sentir com capacidade para, por assim dizer, mudar a natureza humana [...]" (O.C. III, p. 381). É por isso que Rousseau se refere ao legislador como um "homem extraordinário no Estado" (O.C. III, p. 382), dotado de "inteligência superior" (O.C. III, p. 381), cujo ofício não se confunde com os negócios dos homens, uma vez que "não é magistratura, nem é soberania" (O.C. III, p. 382), ou seja, uma função completamente estranha ao corpo político: "Tal ofício, que constitui a república, não pertence à sua

18 A rigor, esse princípio remonta às Leis de Platão (1951), que afirma, no livro VI, ser preciso servir "em primeiro lugar as leis, pois isso é o mesmo que servir os deuses” (cf. Leis, 762e). Ver também o livro X, no qual o diálogo gira em torno da necessidade da crença nos deuses para a obediência efetiva às leis.

19 Uma discussão detalhada acerca da relação entre vontade geral e lei no capítulo "Do legislador" encontrase em meu artigo: KAWAUCHE, 2008, p. 104-111. 
constituição, por ser uma função particular e superior que nada tem de comum com o império humano." (O.C. III, p. 382).

Esse homem superior também se diferencia dos homens comuns por não participar de nenhuma das paixões humanas: lembremos que um dos requisitos do legislador é que ele "visse todas as paixões dos homens e não participasse de nenhuma delas" (O.C. III, p. 381). Não por acaso, o que está em jogo na oposição entre a "razão sublime" e os "homens vulgares" (O.C. III, p. 383384) é precisamente a influência das paixões sobre a atividade de redação das leis, donde segue o princípio de separação entre o poder legislativo e o poder executivo: "Aquele, pois, que redige as leis, não tem nem deve ter nenhum direito legislativo." (O.C. III, p. 383). Pois, se o legislador também governasse os homens, "suas leis, instrumentos de suas paixões, frequentemente não fariam mais do que perpetuar suas injustiças e jamais ele poderia evitar que pontos de vista particulares alterassem a santidade de sua obra" (O.C. III, p. 382). A "santidade" da obra política do legislador diz respeito ao fato miraculoso de ele ser alguém que não cede à tentação humana de tornar-se um tirano, mesmo sendo uma autoridade capaz de mudar até mesmo a natureza dos indivíduos, como um deus. Ou seja, a própria figura do legislador reflete o procedimento adotado em seu discurso, a saber, o de misturar as coisas humanas às coisas divinas - no caso, as leis humanas e as leis divinas, ou ainda, política e religião -, muito embora os elementos dessa mistura sejam de difícil combinação, exigindo nada menos que uma "razão sublime" e uma "inteligência superior" para ocorrer, ou, nas palavras do próprio Rousseau, algo que confere às leis um "caráter extraordinário".

A santidade e o caráter extraordinário da missão política do legislador se verifica ainda na expressão mesma da vontade geral em forma de leis, que também se encontra associada à tensão entre o divino e o humano. Basta lembrarmos que, tanto no Manuscrito de Genebra quanto no verbete sobre economia política da Enciclopédia - textos que antecedem e servem de base para o Contrato -, o estabelecimento das leis é descrito pelo pensador genebrino como uma dificuldade insuperável do ponto de vista da ação humana, podendo sua realização ser considerada um milagre. ${ }^{20}$ Mais do que isso, Rousseau estabelece na própria linguagem do legislador uma clara separação entre a esfera das leis, situadas numa instância superior dos deuses, e a dos homens, que vivem no reino inferior das paixões, sendo precisamente a partir dessa bipartição fundamental, esquematizada em termos da oposição 
entre leis divinas e paixões humanas, que podemos compreender o problema colocado por Rousseau acerca da comunicação entre o legislador e o povo. $\mathrm{O}$ que se tem em vista é a distância intransponível verificada entre a linguagem do legislador e a linguagem do vulgo: "há inúmeras espécies de ideias impossíveis de traduzir-se na língua do povo" (O.C. III, p. 383). A separação que se estabelece entre as duas partes é considerada por Rousseau como sendo insuperável na prática (isto é, do ponto de vista humano, que só compreende a linguagem das paixões), fato que simplesmente impossibilitaria que os homens reconhecessem, de um ponto de vista racional, a necessidade das leis. O que fazer então? Vejamos como Rousseau coloca o problema:

A fim de que um povo nascente possa compreender as sãs máximas da política, e seguir as regras fundamentais da razão de Estado, seria necessário que o efeito pudesse tornar-se causa, que o espírito social - que deve ser a obra da instituição presidisse à própria instituição, e que os homens fossem antes das leis o que deveriam tornar-se depois delas. (O.C. III, p. 383)

Antes de tudo, ao que nos parece, trata-se de uma espécie de enigma, cuja solução (caso exista na realidade histórica) seria dada pelo recurso aos deuses por parte do legislador. Seu procedimento discursivo consiste em deslocar a lei, que originalmente se encontra na instância superior das "sãs máximas da política", para uma "de outra ordem", mas igualmente superior: "Desse modo, pois, o Legislador, não podendo empregar nem a força nem o raciocínio, recorre necessariamente a uma autoridade de outra ordem, que possa conduzir sem violência e persuadir sem convencer." (O.C. III, p. 383). Essa "outra ordem" diz respeito à "autoridade divina" que o povo reconhece no legislador: "Essa razão sublime, que escapa ao alcance dos homens vulgares, é aquela cujas decisões o Legislador põe na boca dos imortais, para guiar pela autoridade divina os que a prudência humana não poderia abalar." (O.C. III, p. 383-384). Ou seja, a missão do legislador consiste em fazer com o que os homens obedeçam às leis civis comunicando-as como se estas fossem leis divinas. É, portanto, a linguagem da religião que cumpre o papel de mediadora no estabelecimento do corpo político pelo fato de conseguir combinar elementos a princípio incompatíveis das coisas humanas e das coisas divinas, ou seja, misturar religião e política por meio de um recurso estilístico, de modo a fazer o povo acreditar na possibilidade de uma superação dos conflitos entre Igreja e Estado, o que asseguraria a unidade do corpo político instituído mediante o pacto civil.

O legislador é, pois, uma espécie de guia espiritual do corpo político, que, no momento da instituição das leis, conduz os homens sem violência e os per- 
suade sem convencê-los, recorrendo em seu discurso à autoridade divina para comunicar ao povo nascente a vontade geral em forma de leis determinadas, visto que a "multidão cega" (O.C. III, p. 380) não é capaz de discernir, por si só, a verdade geral e abstrata do bem comum que procura. O procedimento discursivo do legislador consiste em comunicar as leis civis como se estas fossem leis divinas, utilizando um tópos da teologia segundo o qual as leis seriam a expressão terrena (ou política) da vontade geral, que, por ser santa e sublime, estaria situada em uma instância infinitamente superior e, portanto, só poderia se acessada por alguns indivíduos especiais, que seriam - digamos assim - os apóstolos das "sãs máximas da política": "Haveria necessidade de deuses para dar leis aos homens" (O.C. III, p. 381), afirma Rousseau. Podemos então perceber que a tensão entre o divino e o humano não desaparece no texto analisado, ainda que a função do legislador seja precisamente mostrar, de um ponto de vista puramente civil, um caminho de conciliação entre esses pólos tão distantes um do outro: o povo deve se submeter às leis do Estado como às das natureza, e também deve reconhecer que o poder que forma o homem é o mesmo que forma a Cidade (logo, um poder ao mesmo tempo civil e teológico), de tal maneira que os cidadãos possam acreditar que obedecer às leis é o mesmo que obedecer aos deuses, muito embora nunca se saiba ao certo quando se está fazendo uma coisa ou outra, haja vista a aparente fusão que Rousseau opera entre os termos. Rousseau se preocupa menos em explicar como o problema poderia ser resolvido do que em colocá-lo de uma maneira adequada, como um orador que busca a adesão de seu auditório para o princípio sublime da unidade do Estado: princípio este que o auditório mesmo, multidão cega preocupada apenas com os interesses imediatos, jamais seria capaz de compreender a não ser por um procedimento discursivo prodigioso, tal qual o que se opera no registro do próprio texto do Contrato.

Neste artigo, procuramos evidenciar o expediente retórico por meio do qual Rousseau estabelece a relação entre religião e política no Contrato social. Nossa análise concentrou-se na combinação inusitada entre vocábulos de religião e de política, encontrada em expressões como "santidade do contrato social e das leis", "profissão de fé puramente civil" e "religião civil", que na terminologia da retórica se aproxima da figura de linguagem denominada oxímoro. Além disso, identificamos, no Contrato, esse mesmo expediente retórico no procedimento discursivo associado à figura do legislador, que precisa conferir caráter santo ou divino às leis civis a fim de realizar o milagre 
de comunicar a vontade geral ao povo, o que, por sua vez, aponta para o mesmo modo de expressão por meio do qual o próprio Rousseau define uma via intermediária entre pares de opostos, baseada na tentativa de relacionar termos inconciliáveis da religião e da política.

\section{Referências bibliográficas}

ALTHUSSER, Louis. "Sur le Contrat Social". Cahiers pour l'Analyse, Paris, n. 8, 1967.

BELLAH, Robert N. "Civil Religion in America" [1967]. In: . Beyond Belief: Essays on Religion in a Post-Traditional World. Berkeley; Los Angeles: University of California Press, 1991.

BERNARDI, Bruno. La Fabrique des concepts: recherches sur l'invention conceptuelle chez Rousseau. Paris: Honoré Champion, 2006.

. "La religion civile, institution de tolérance?". In: MOSTEFAI, Ourida; SCOTT, John T. (Ed.). Rousseau and l'Infâme: Religion, Toleration and Fanaticism in the Age of Enlightenment. Amsterdam: Rodopi, 2009.

COTTA, Sergio. "Théorie religieuse et théorie politique chez Rousseau”. In: Rousseau et la philosophie politique. Paris: Presses Universitaires de France, 1965.

CRISTI, Marcela. From Civil to Political Religion: The Intersection of Culture, Religion and Politics. Waterloo, Canada: Wilfrid Laurier University Press, 2001.

CULOMA, Michaël. La Religion civile de Rousseau à Robespierre. Paris: L'Harmattan, 2010.

FERRARI, Jean. "De la religion civile dans la pensée politique de Jean-Jacques Rousseau". Études Jean-Jacques Rousseau, Montmorency, v. 7, 1995.

GOLDSCHMIDT, Victor. "Rousseau et le droit". In: . Écrits, t. 2. Paris: J. Vrin, 1984.

GOUHIER, Henri. Les Méditations métaphysiques de Jean-Jacques Rousseau. Paris: J. Vrin, 1984.

GOYARD-FABRE, Simone. Politique et philosophie dans l'oeuvre de Jean-Jacques Rousseau. Paris: Presses Universitaires de France, 2001.

JIMACK, Peter. "Rousseau and 'la beauté de l'Évangile". French Studies, Oxford, v. $19,1965$.

KAWAUCHE, Thomaz. "Sobre a imagem rousseauniana da lei acima dos homens". Trans/Form/Ação, São Paulo, v. 31(2), 2008. [http://www.scielo.br/pdf/trans/v31n2/06. pdf]

MASSON, Pierre-Maurice. La Religion de Jean-Jacques Rousseau. Paris: Hachette, 1916, $3 \mathrm{v}$.

MASTERS, Roger D. The Political Philosophy of Rousseau. Princeton: Princeton University Press, 1968.

PEZZILLO, Lelia. Rousseau et le Contrat social. Paris: Presses Universitaires de France, 2000. 
PISSARRA, Maria Constança Peres. Religião civil e intolerância: uma análise das “Lettres Écrites de la Montagne”. Dissertação (Mestrado). São Paulo, 1988. Pontifícia Universidade Católica de São Paulo.

PLATON. Les Lois (livres III-VI). Trad. Édouard des Places (S.J.). Paris: Les Belles Lettres, 1951 (Oeuvres Complètes de Platon, t. XI-2).

ROUSSEAU, Jean-Jacques. Oeuvres complètes. Ed. Bernard Gagnebin e Marcel Raymond. Paris: Gallimard, 1959-1995, 5 v. (Col. "Bibliothèque de la Pléiade"). . O contrato social. Trad. Antonio de Pádua Danesi. $3^{\mathrm{a}}$ ed. São Paulo: Martins Fontes, 2003.

SALINAS FORTES, Luiz Roberto. Paradoxo do espetáculo: política e poética em Rousseau. São Paulo: Discurso Editorial, 1997.

TALMON, Jacob Leib. The Origins of Totalitarian Democracy. London: Secker \& Warburg, 1952.

VARGAS, Yves. Introduction à l'Emile de Jean-Jacques Rousseau. Paris: Presses Universitaires de France, 1995.

WATERLOT, Ghislain. Rousseau: religion et politique. Paris: Presses Universitaires de France, 2004. 